\title{
Metabolic activity of rat hepatocytes cultured on homologous acellular matrix and transplanted into Gunn rats
}

\author{
SILVIA TOMAT $^{1 *}$, PATRIZIA BURRA ${ }^{1 *}$, ENRICO GRINGERI $^{1}$, UMBERTO CILLO $^{1}$, \\ FIORELLA CALABRESE ${ }^{2}$, CINZIA GIACOMETTI ${ }^{2}$, PAOLO CARRARO $^{5}$, CARLO MACCHI $^{4}$, \\ GASTONE G. NUSSDORFER ${ }^{4}$ and PIER PAOLO PARNIGOTTO ${ }^{3}$
}

\begin{abstract}
Departments of ${ }^{1}$ Surgical and Gastroenterological Sciences, ${ }^{2}$ Pathological Anatomy, ${ }^{3}$ Pharmaceutical Sciences, ${ }^{4}$ Human Anatomy and Physiology, ${ }^{5}$ Laboratory of Analysis University Hospital, University of Padua, I-35121 Padua, Italy
\end{abstract}

Received May 17, 2006; Accepted July 12, 2006

\begin{abstract}
The metabolic activity of hepatocytes cultured on homologous acellular matrix (HAM) and transplanted into rats genetically incapable of bilirubin conjugation (Gunn rats) has been investigated. Hepatocytes from Wistar male rats were seeded on HAM and cultured for 9 days, and the proliferation rate and albumin mRNA expression were assayed daily. HAM alone or HAM plus hepatocytes (cultured for 3 days) were implanted in a subcutaneous pocket of the dorsal region of Gunn rats. No immunosuppression therapy was used. Blood samples were collected weekly and rats were sacrificed 10 weeks after surgery. Hepatocytes cultured on HAM displayed a higher proliferation rate than those cultured on plastic, and albumin mRNA expression was detected in hepatocytes seeded on HAM, but not on plastic. Serum bilirubin concentrations did not differ from baseline values in both the sham-operated control and HAM transplanted rats. On the contrary, in rats transplanted with HAM plus hepatocytes, circulating bilirubin levels decreased from week 4-7, and then plateaued until week 10. Histology did not evidence signs of rejection, but only a mild degree of inflammation around the implanted patches. It is concluded that hepatocytes seeded on HAM and transplanted into Gunn rats are able to metabolize bilirubin for at least two months, without signs of rejection even in the absence of immunosuppressive therapy.
\end{abstract}

\section{Introduction}

Liver transplantation is currently the only well-established treatment for patients with acute or end-stage liver failure,

Correspondence to: Dr Patrizia Burra, Department of Surgical Gastroenterological Sciences, Gastroenterology, Liver Transplantation Unit, University of Padua, Via Giustiniani 2, I-35128 Padua, Italy E-mail: burra@unipd.it

${ }^{*}$ Contributed equally

Key words: hepatocytes, homologous acellular matrix, bilirubin metabolism, Gunn rats and inherited metabolic disorders (1). However, liver transplantation is still limited by organ availability (2) and, consequently, great interest has been developed in the field of cell transplantation and tissue engineering as an alternative to organ transplantation (3-8).

A number of issues concerning hepatocyte transplantation $(9,10)$ or their use in bioartificial livers $(11)$ have attracted investigative attention during the past three decades. Early studies established that syngeneic hepatocytes can survive, proliferate and normally express several genes when transplanted in many ectopic sites, such as the spleen, peritoneal cavity and dorsal fat pad $(12,13)$. However, progress in this area has been severely limited, especially because anchorage is needed for hepatocytes to survive (14) and the various available tested biomaterials are eventually degraded and resorbed (15). Also the induction of inflammatory and/or fibrotic responses in the hosts interferes with the survival of hepatocytes transplanted in microcapsule barriers and neoorganogenesis settings (16). Hence, several difficulties have to be overcome for the development of a satisfactory bioartificial liver device (17), and efforts are ongoing to determine whether allogeneic hepatocytes can be immunoisolated in biomaterials to prevent rejection (18).

Numerous factors have been proven to play a relevant role in preserving the viability and differentiated function of hepatocytes cultured in vitro, among which are the existence of active cell-cell interactions and cell-extracellular matrix contacts (19-21). Many tissue-engineered devices have been proposed to provide structural and functional support to transplanted cells similar to that of the native tissue they should replace (22). The culture configuration has been reported to have a major impact on cell differentiation, and the sandwich configuration appears to be the best one, because it promotes hepatocyte growth (23) and differentiated functions (albumin secretion, detoxification capacity, and bilirubin and urea metabolite clearance) (24-26).

Hepatocyte transplantation has been studied in a number of animal models with liver-based metabolic disorders, including Gunn rats (27-30). The Gunn rat is an animal model of the Crigler-Najjar syndrome type 1, where the mutant strain of Wistar rats lacks bilirubin-UDP-glucuronosyltransferase activity and consequently accumulates toxic levels of unconjugated bilirubin (31). The aim of the present study 
was to assess the metabolic activity of isolated rat hepatocytes cultured on homologous acellular matrix (HAM) in sandwich configuration, and then transplanted into Gunn rats.

\section{Materials and methods}

Animals and reagents. Adult male Wistar rats (250-320 g body weight) were purchased from Charles-River (Como, Italy), and Gunn rats from Harlan (S. Pietro al Natisone, Italy). Animals were maintained on a 12:12-h dark/light cycle at $23^{\circ} \mathrm{C}$, with free access to rat chow and tap water. The experiment protocol was approved by the local Ethics Committee for Animal Studies, and experiments were carried out according to the Italian Animal Act (Law 116/92). Tiletamine and zolazepam chloridrate were obtained from Laboratoires VIRBAC (Carros, France), and xilazine chloridrate from Bayer AG (Leverkusen, Germany). HepatoSTIM culture medium was provided by Becton-Dickinson Labware (Bedford, MA). 5'-Bromo-2'-deoxyuridine (BrdU), phosphate buffered saline (PBS), and all other chemicals and laboratory reagents were purchased from Sigma-Aldrich Corp. (St. Louis, MO).

HAM preparation. Liver matrix was prepared the day before each experiment from Wistar rats, according to Meezan et al (32), with few modifications (33). HAM was stored in PBS at $4^{\circ} \mathrm{C}$ until use.

Hepatocyte culture. Hepatocytes were isolated from Wistar rats, as previously described (33). Dispersed cells were seeded $\left(1.6 \times 10^{5} / \mathrm{cm}^{2}\right)$ into a 24-well plate, whose wells were uncoated or previously coated with HAM. Hepatocytes were cultured in Hepato-STIM medium for up to 9 days, the medium being changed every $24 \mathrm{~h} \mathrm{(33)}$.

Cell proliferation. The proliferation rate of hepatocytes was evaluated at day 3, 5, 7 and 9 of culture, using a colorimetric immunoassay (Cell proliferation ELISA kit; Roche Molecular Biochemicals, Mannheim, Germany), based on the measurement of BrdU incorporation during DNA synthesis (34). BrdU was added (10 $\mu \mathrm{l} /$ well of $10 \mathrm{mM}$ BrdU solution in PBS, pH 7.4) to the cultures and cells were reincubated for $4 \mathrm{~h}$ at $37^{\circ} \mathrm{C}$, then the manufacturer's instructions were followed.

Reverse transcription (RT)-polymerase chain reaction (PCR). RNA was extracted from hepatocytes cultured on plastic or HAM at day 3, 5, 7 and $9(35,36)$, and PCR was carried out, as detailed previously $(37,38)$, in a DNA Thermal Cycler (Perkin-Elmer Life Sciences, Milan, Italy). The following primers, designed to amplify a region of the rat albumin gene spanning exons G-H-I (39), were used: sense, 5'-GCAGAA ATCCCAGTGTCTCG-3' and antisense, 5'-CCAAGCTTCT CGTAAAGCTC-3' (345 bp). The amplification program was denaturation $\left(94^{\circ} \mathrm{C}\right.$ for $\left.60 \mathrm{sec}\right)$, annealing $\left(56^{\circ} \mathrm{C}\right.$ for $\left.60 \mathrm{sec}\right)$ and extension $\left(72^{\circ} \mathrm{C}\right.$ for $\left.60 \mathrm{sec}\right)$ for a total of 30 cycles.

HAM implantation. Hepatocytes were cultured on HAM for 3 days, then HAM was lifted as a sheet by a sterile scraper and prepared for implantation. Gunn rats were anesthesized with tiletamine and zolazepam chloridrate $(40 \mathrm{mg} / \mathrm{kg})$ and xilazine chloridrate $(2 \mathrm{mg} / \mathrm{kg})$, and HAM alone $(\mathrm{n}=12)$ or hepatocyte $\left(10^{6}\right.$ cells $)$-HAM sandwiches $(n=13)$ were implanted in a subcutaneous pouch of their dorsal region (Fig. 1). Control animals $(n=10)$ were sham-operated. No immunosuppression therapy was used. Rats were killed 10 weeks after surgery.

Bilirubin serum concentration. Blood samples $(600 \mu 1)$ were collected from the tail vein of all rats 2 days before surgery and thereafter weekly until sacrifice. Bilirubin concentration was measured by a colorimetric method in the Laboratory of Analysis, Padua Hospital ULSS 16.

Histology. The liver and the cutaneous-subcutaneous tissue around the implants were examined. Samples were fixed in $10 \%$ neutral formalin and embedded in paraffin. Sections $(\sim 5 \mu \mathrm{m}$

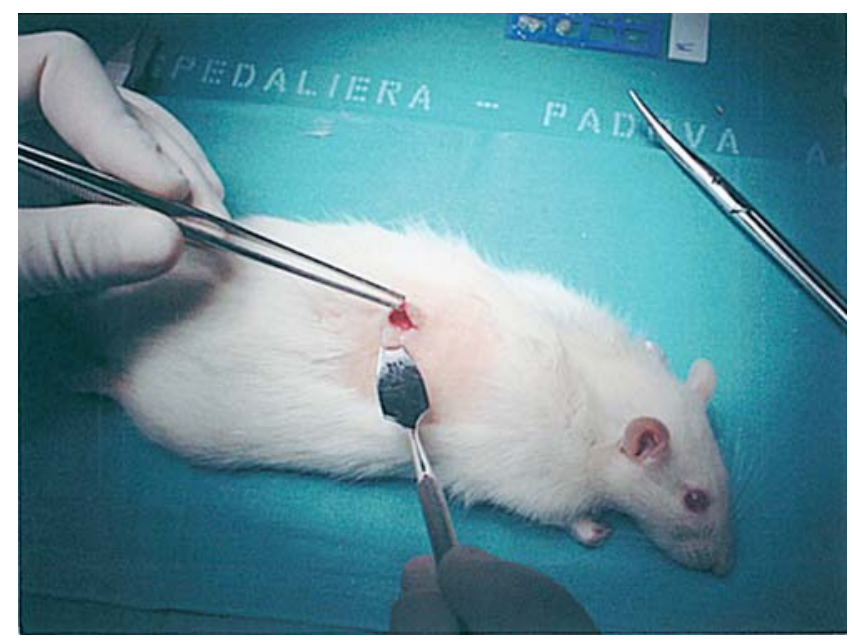

Figure 1. Implantation of the hepatocyte-HAM sandwich into a subcutaneous pouch of the dorsal region of a Gunn rat.

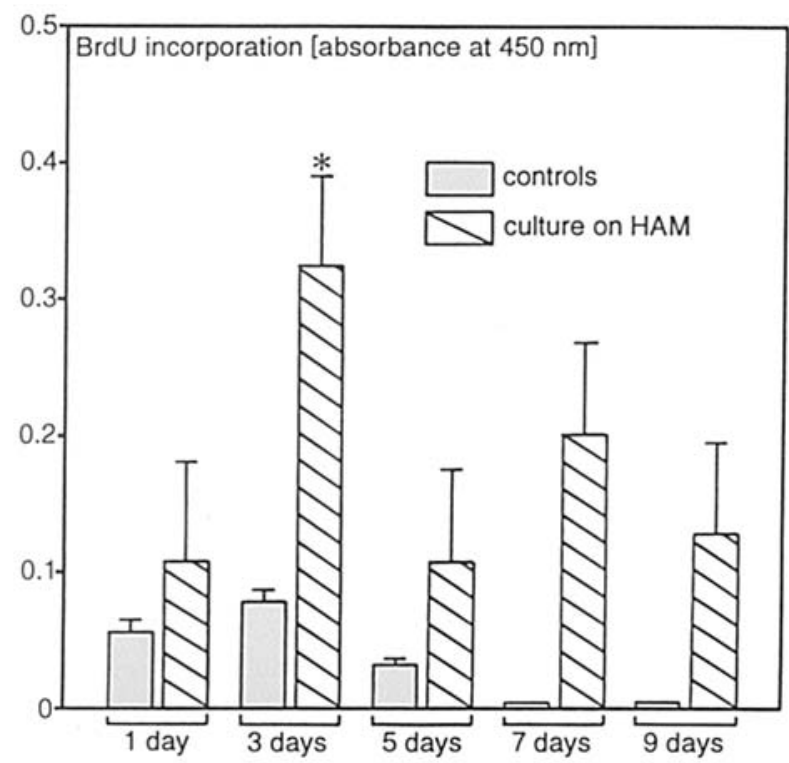

Figure 2. Proliferation rate of hepatocytes cultured on plastic (controls) or on HAM-coated wells. Bars are means $\pm S D(n=6)$. ${ }^{*} \mathrm{p}<0.05$ for the respective control group. 


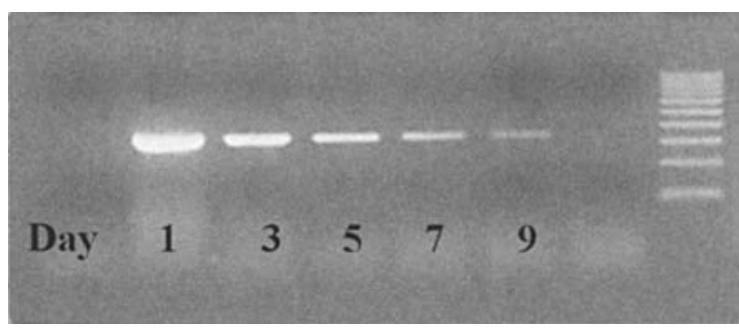

Figure 3. Ethidium bromide-stained $1 \%$ agarose gel showing cDNA amplified with rat albumin specific primers from RNA of hepatocytes cultured on HAM for 1, 4, 5, 7 and 9 days. No amplification with water instead of RNA is shown as negative control (penultimate lane). Last lane was loaded with $200 \mathrm{ng}$ of the size marker VIII (Boehringer Ingelheim $\mathrm{GmbH}$, Mannheim, Germany).

thick) were stained with hematoxylin-eosin or PAS to evaluate liver glycogen content. In the liver tissue, the extent of sinusoid congestion, necrosis, steatosis and glycogen content were evaluated, using the following 4-step (0-3) score: 0 , absent; 1 , mild or $<30 \%$ of cells; 2 , moderate or $30-60 \%$ of cells; and 3 , severe or $>60 \%$ of cells). In the cutaneoussubcutaneous samples, the presence of HAM or hepatocyteHAM sandwich was assessed, together with the exent and type of inflammation.

Statistics. Values were expressed as means \pm SD, and their statistical analysis was performed by ANOVA followed by the Bonferroni test.

\section{Results}

The proliferation rate of hepatocytes cultured on HAM was higher than that of hepatocytes cultured on plastic but, due to the very high variability, the difference reached significance only at day 3 of culture (Fig. 2). RT-PCR detected the expression of albumin mRNA in hepatocytes cultured on HAM (Fig. 3), but not in those cultured on plastic (data not shown).

Baseline bilirubin serum concentration was similar in all groups of Gunn rats, and did not display significant changes in both control and HAM-implanted animals. In contrast, it steadily decreased from week 4 to 7 and then plateaued until

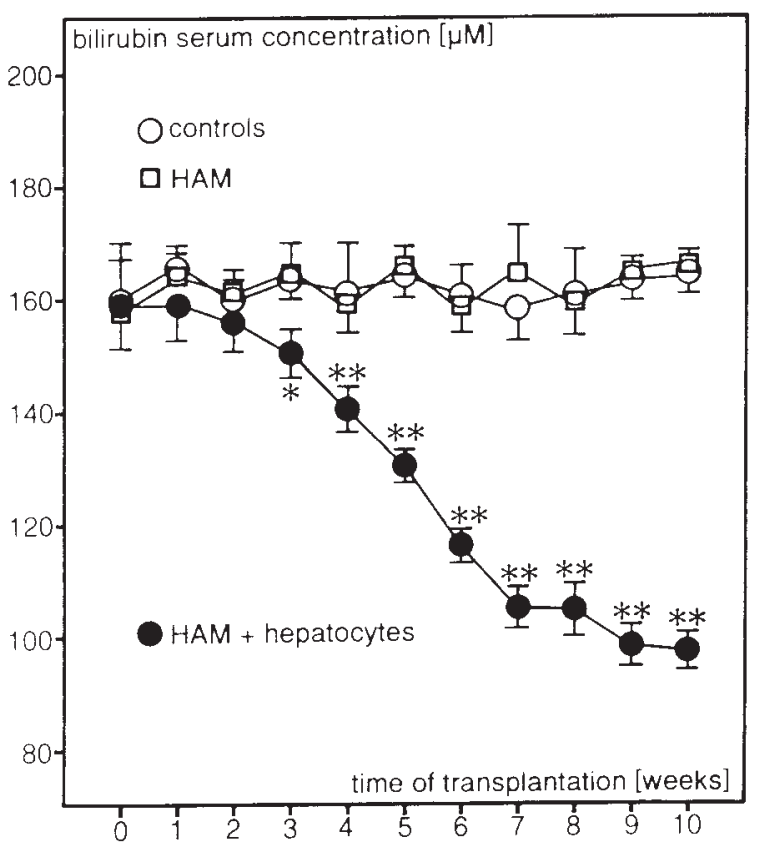

Figure 4. Bilirubin serum concentration in sham-operated control $(n=10)$ and HAM $(n=12)$ or hepatocyte-HAM-implanted $(n=13)$ Gunn rats, as a function of the time elapsed from surgery. Points are means $\pm \mathrm{SD} .{ }^{*} \mathrm{p}<0.05$ and ${ }^{* *} \mathrm{p}<0.01$ for the respective control group.

week 10 in rats implanted with hepatocyte-HAM sandwiches (Fig. 4).

Liver tissue showed a well-preserved architecture in all groups of Gunn rats, without relevant signs of sinusoidal congestion, steatosis and necrosis (Table I). Glycogen stores were depleted in both groups of implanted rats as compared to control animals (Table I). The inflammation around implants was mostly of a mild degree (Fig. 5), and no marked differences were observed in terms of extension and type of inflammation between HAM- and hepatocyte-HAMimplanted groups of rats (Table II).

\section{Discussion}

Hepatocyte transplantation, based on the use of liver cells instead of the whole organ for the replacement of liver

Table I. Semiquantitative histological evaluation of liver in control and transplanted rats.

\begin{tabular}{|c|c|c|c|}
\hline Parameter & $\begin{array}{l}\text { Control rats } \\
\qquad(\mathrm{n}=10)\end{array}$ & $\begin{array}{l}\text { HAM-implanted rats } \\
\qquad(\mathrm{n}=12)\end{array}$ & $\begin{array}{l}\text { Hepatocyte-HAM-implanted rats } \\
\qquad(\mathrm{n}=13)\end{array}$ \\
\hline Sinusoid congestion & $0.28 \pm 0.48$ & $\begin{array}{c}0.50 \pm 0.52 \\
\mathrm{NS}\end{array}$ & $\begin{array}{c}0.42 \pm 0.53 \\
\mathrm{NS}\end{array}$ \\
\hline Steatosis & $0.42 \pm 0.53$ & $\begin{array}{l}0.10 \pm 0.30 \\
\mathrm{NS}\end{array}$ & $\begin{array}{l}0.40 \pm 0.51 \\
\quad \mathrm{NS}\end{array}$ \\
\hline Necrosis & 0 & 0 & 0 \\
\hline Glycogen storage & 3 & $\begin{array}{l}1.62 \pm 0.69 \\
\mathrm{p}<0.001\end{array}$ & $\begin{array}{c}2.14 \pm 0.68 \\
\mathrm{p}<0.05\end{array}$ \\
\hline
\end{tabular}




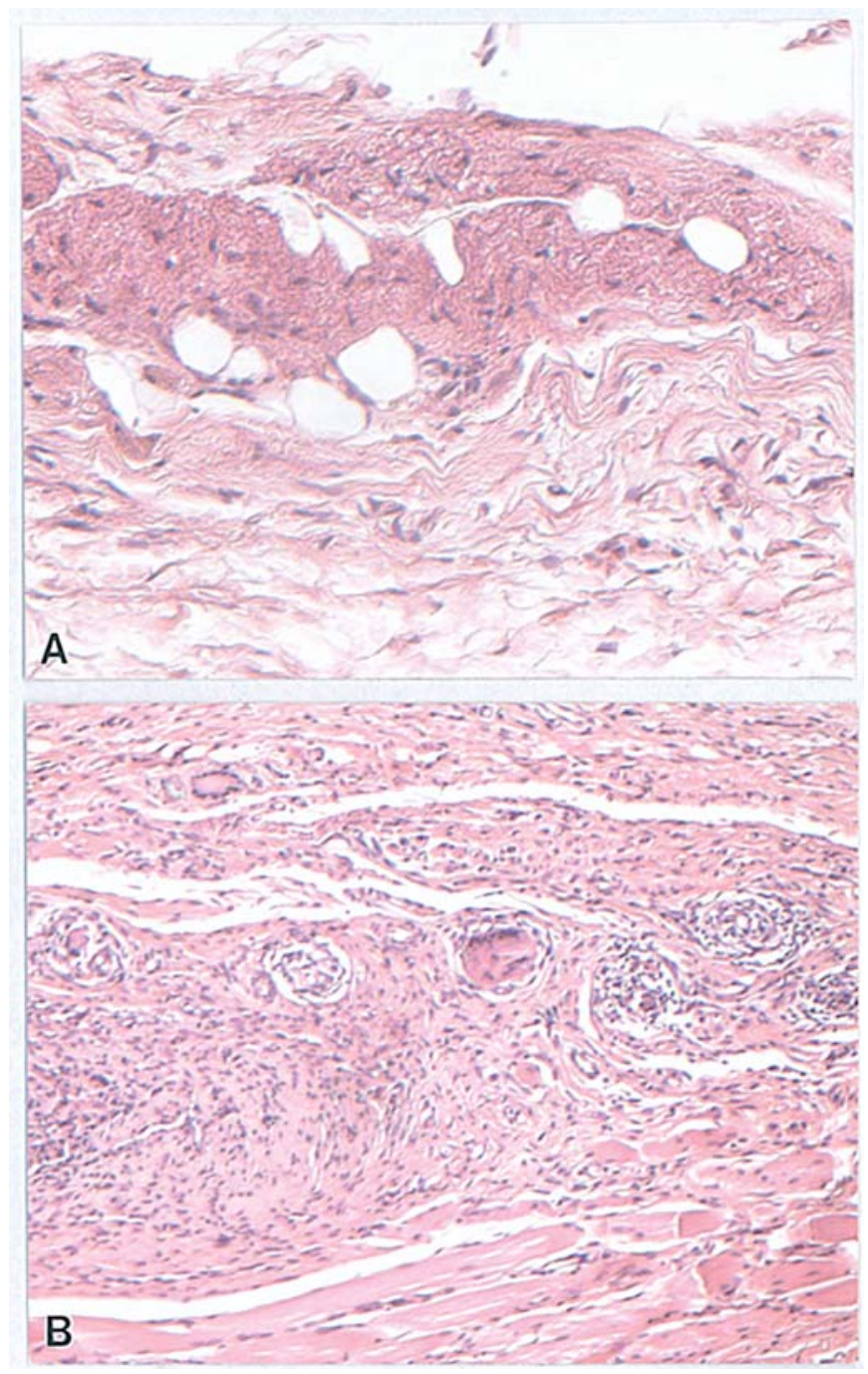

Figure 5. Histology of HAM (A) and hepatocyte-HAM sandwich (B) implants, 10 weeks after surgery. A mild inflammatory response is present only in B. Hematoxylin-eosin. Magnification: A, x40; B, x25. function, is a 'bridge' until organ transplantation is possible or regeneration occurs (1). Two fundamental requirements are needed for the success of hepatocyte transplantation: i) a minimum amount of hepatocytes, which may provide a sufficient metabolic support to the recipient; and ii) an adequate hepatotrophic stimulation of transplanted cells. Moreover, the location (orthotopic or heterotopic) of the implant is crucial for complete success (40).

A period of culture on a support providing hepatotrophic stimulation may allow an increase in the number and function of hepatocytes (41). Several possible devices have been proposed, including the coating of culture dishes with extracellular matrix molecules (42), the addition of growth hormones and cytokines to the culture medium (43), and coculture with other cell types $(44,45)$. Previous studies demonstrated that HAM favors the viability and the maintenance of metabolic functions (i.e. albumin and urea nitrogen production) of hepatocytes in primary culture (33), and our present results confirm and extend this contention.

Hepatocytes have a huge capacity to proliferate in vivo, but their ability to grow in culture is limited $(46,47)$. Our present findings, although affected by a great variability, indicate that HAM is able not only to maintain the viability of cultured hepatocytes, but also to promote their proliferation. However, this HAM effect is not very intense, and we are trying to ascertain whether the coculture with bone marrowderived stromal cells (48) is able to magnify it. Albumin is the predominant and characteristic product of the adult liver, and, therefore, its synthesis is a convenient example of controlled gene expression in fully differentiated hepatocytes (49). Albumin has been previously detected in the medium of hepatocytes cultured on HAM (33), but it is essential to distinguish newly synthesized albumin from that released from dead hepatocytes (50). The present demonstration where hepatocytes cultured on HAM expressed albumin mRNA indicates that they are actually able to synthesize this protein.

Table II. Histological evaluation of the cutaneous-subcutaneous tissue around HAM and hepatocyte-HAM implants.

\section{Parameters}

HAM implant

$(n=12)$

Extent of inflammation

$\begin{array}{lll}\text { Absent } & 1 & 0 \\ \text { Mild } & 6 & 6 \\ \text { Moderate } & 3 & 3 \\ \text { Severe } & 2 & 4\end{array}$

Type of inflammation

Absent

Granulocytic (acute)

Lymphomonocytic (chronic)

Granulomatous (foreign body)

Cutaneous necrosis/ulceration

Absent

1

1

3

Data indicate the number of cases. 
Taken together, the findings discussed above strongly suggest that hepatocytes cultured on HAM can be successfully used in transplants aimed to support impaired liver function, and we have verified this contention in Gunn rats, whose livers are genetically unable to conjugate bilirubin $(26,31)$. We found that the implant of a hepatocyte-HAM sandwich is able to restore this liver function in the Gunn strain. Moreover, our hepatocyte transplantation technique has some advantages in comparison to the other techniques currently employed, and this will be briefly discussed below.

Hepatocytes with their support have been previously inserted either into the peritoneal cavity, which offers a large space for hepatocyte engraftment, but scarce attachment and survival of transplanted cells (27), or into the liver after partial hepatectomy, which provides a favorable environment, but does not allow transplanted cells to be distinguished from those of the recipient $(18,51)$. We chose to implant the hepatocyte-HAM sandwich in a subcutaneous pocket of the dorsal region of the Gunn rat, which offers some revelevant advantages, such as easy surgical technique and identification of the implanted hepatocytes.

The observation that most functional liver proteins are produced in great excess led to the assumption that the transplantation of only a small fraction of the total hepatocyte mass $(\sim 1-5 \%)$ should be able to correct many liver metabolic disorders. However, experimental and clinical studies did not meet this expectation (52). The transplantation of a relatively large number of hepatocytes is needed, but this has been shown to require heavy immunosuppression $(53,54)$. To overcome this difficulty, some investigators proposed the use of immunoisolated membranes enveloping hepatocytes, but this technique allows the implant of no more than 5.0$7.5 \times 10^{5}$ cells and the functionality of the implant lasts no longer than 30 days $(55,56)$. In our study we successfully transplanted small amounts of hepatocytes $\left(10^{6}\right.$ cells $)$, which were able to partially restore the ability of the Gunn rat liver to conjugate bilirubin for at least 10 weeks. The antigenicity of our hepatocyte-HAM sandwiches is conceivably very low, inasmuch as only a mild inflammatory response without signs of rejection has been observed around the implants, even in the absence of immunosuppressive therapy.

Collectively, our findings lead us to conclude that the transplantation of hepatocytes cultured on HAM is a very reliable and promising technique allowing the long-term support of liver metabolic functions. However, it must be pointed out that restoration of bilirubin-conjugation activity occurs for no more than $40 \%$ after $7-10$ weeks from transplantation. The possibility that this is due to a decrease in the activity of transplanted hepatocytes is unlikely, because the concentration of circulating bilirubin plateaus, but does not increase from the 7 th to the 10th week after surgery. More probable is that too small a number of hepatocytes has been transplanted, and investigations aimed at checking this contention are currently under way.

\section{Acknowledgments}

This study was supported by a grant from the University of Padua (Progetto di Ateneo 2003 CPDA 037549).

\section{References}

1. Keeffe EB: Liver transplantation: current status and novel approaches to liver replacement. Gastroenterology 120: 749-762, 2001.

2. Ogawa K, Ochoa ER, Borenstein J, Tanaka K and Vacanti JP: The generation of functionally differentiated, three-dimensional hepatic tissue from two-dimensional sheets of progenitor small hepatocytes and nonparechymal cells. Transplantation 77: 1783-1789, 2004.

3. Vacanti JP, Morse MA, Saltzman WM, Domb AJ, Perez-Atayde A and Langer R: Selective cell transplantation using bioabsorbable artificial polymers as matrices. J Pediatr Surg 23: 3-9, 1988.

4. Langer R and Vacanti JP: Tissue engineering. Science 260: 920-926, 1993.

5. Malhi $\mathrm{H}$ and Gupta S: Hepatocyte transplantation: new horizons and challenges. J Hepatobiliary Pancreat Surg 8: 40-50, 2001.

6. Pollock JM and Vacanti JP: Tissue engineering. Semin Pediatr Surg 5: 191-196, 1996.

7. Rifai K, Ernst T, Kretschmer U, Bahr MJ, Schneider A and Hafer C: Prometheus: a new extracorporeal system for the treatment of liver failure. J Hepatol 39: 984-990, 2003.

8. Strain AJ and Neuberger JM: A bioartificial liver: state of the art. Science 295: 1005-1009, 2002

9. Gupta S, Rajvanshi P, Bhargava KK and Kerr A: Hepatocyte transplantation: progress toward liver repopulation. Prog Liver Dis 14: 199-222, 1996

10. Gupta S, Gorla GR and Irani AN: Hepatocyte transplantation: emerging insight into mechanism of liver repopulation and their relevance to potential therapies. J Hepatol 30: 162-170, 1999.

11. Grant MH, Morgan C, Henderson C, Malsch G, Seifert B, Albrecht W and Groth T: The viability and function of primary rat hepatocytes cultured on polymeric membranes developed for hybrid artificial liver devices. J Biomed Mater Res A 73: 367-375, 2005.

12. Vemuru RP, Devidson A, Aragona E, Burk RD, Chowdhury JR and Gupta S: Immune tolerance to a defined heterologous antigen following intrasplenic hepatocyte transplantation: implications for human gene therapy. FASEB J 6: 2836-2842, 1992.

13. Gupta S, Vemuru RP, Lee CD, Yerneni PR, Aragona E and Burk RD: Hepatocytes exhibit superior transgene expression after transplantation into liver and spleen compared with peritoneal cavity or dorsal fat pad: implication for hepatic gene therapy. Hum Gene Ther 5: 959-967, 1994.

14. Terada S, Sato M, Sevy A and Vacanti JP: Tissue engineering in the twenty-first century. Yonsei Med J 41: 685-691, 2001.

15. Vacanti JP and Langer R: Tissue engineering: the design and fabrication of living replacement devices for surgical reconstruction and transplantation. Lancet 354: S132-S134, 1999.

16. Davies MW and Vacanti JP: Toward development of an implantable tissue engineered liver. Biomaterials 17: 365-372, 1996.

17. Chan C, Berthiaume F, Nath BD, Tilles AW, Toner M and Yarmush ML: Hepatic tissue engineering for adjunct and temporary liver support: critical technologies. Liver Transpl 10: 1331-1342, 2004.

18. Dixit V, Darvasi R, Arthur M, Brezina M, Lewin K and Gitnick G: Restoration of liver function in Gunn rats without immunosuppression using transplanted microencapsulated hepatocytes. Hepatology 12: 1342-1349, 1990.

19. Olive PL and Durand RE: Drug and radiation resistance in spheroids: cell contact and kinetics. Cancer Metastasis Rev 13: 121-138, 1994.

20. Yamada K, Kamihira M, Hamamoto R and Iijima S: Efficient induction of hepatocyte spheroids in a suspension culture using a water-soluble synthetic polymer as an artificial matrix. J Biochem 123: 1017-1023, 1998.

21. Wu FJ, Friend JR, Hsiao CC, Zilliox MJ, Ko WJ, Cerra FB and $\mathrm{Hu}$ WS: Efficient assembly of rat hepatocyte spheroids for tissue engineering applications. Biotechnol Bioeng 50: 404-415, 1995.

22. Kamihira M, Yamada K, Hamamoto R and Iijima S: Spheroid formation of hepatocytes using synthetic polymer. Ann NY Acad Sci 831: 398-407, 1997.

23. Berthiaume F, Moghe PV, Toner M and Yarmush ML: Effect of extracellular matrix topology on cell structure, function, and physiological responsiveness: hepatocytes cultured in a sandwich configuration. FASEB J 10: 1471-1484, 1996. 
24. Guguen-Guillouzo C, Clement B, Baffet G, Beaumont C, Morel-Chany E, Claise D and Guillouzo A: Maintenance and reversibility of active albumin secretion by adult rat hepatocytes co-cultured with another liver epithelial cell type. Exp Cell Res 143: 47-54, 1983.

25. Takeda T, Kim TH, Lee SK, Langer R and Vacanti JP: Hepatocyte transplantation in biodegradable polymer scaffolds using Dalmatian dog model of hyperuricosuria. Transplant Proc 27: 635-636, 1995.

26. Thummala NR, Ghosh SS and Lee SW: A non-immunogenic adenoviral vector, coexpressing CTLA4Ig and bilirubinuridinediphosphoglucuronateglucuronosyl-transferase permits long-term, repeatable transgene expression in the Gunn rat model of Crigler-Najjar syndrome. Gene Ther 9: 981-990, 2002.

27. Demetriou AA, Levenson SM, Novikff AB, Chowdhury NR, Whiting J, Reisner A and Chowdhury JR: Survival, organization, and function of microcarrier-attached hepatocytes transplanted in rats. Proc Natl Acad Sci USA 83: 7475-7479, 1986.

28. Attaran M, Schneider A, Grote C, Zwiens C, Flemming P, Gratz KF, Jockheim A, Bahr MJ, Manns MP and Ott M: Regional and transient ischemia/reperfusion injury in the liver improves therapeutic efficacy of allogenic intraportal hepatocyte transplantation in low-density lipoprotein receptor deficient Watanabe rabbits. J Hepatol 41: 837-844, 2004.

29. Malhi H, Hirani AN, Volenberg I, Schilsky ML and Gupta S: Early cell transplantation in LEC rats modeling Wilson's disease eliminated hepatic copper with reversal of liver disease. Gastroenterology 122: 438-447, 2002.

30. Guha C, Parashar B and Deb NJ: Normal hepatocyte correct serum bilirubin after repopulation of Gunn rat liver subjected to irradiation/partial resection. Hepatology 36: 354-362, 2002.

31. Chowdhury JR and Jansen PLM: Bilirubin metabolism and its disorder. In: Hepatology. Zakim D and Boyer TD (eds). WB Saunders, Philadelphia, pp323-361, 1996.

32. Meezan E, Hyelle JT and Brendel K: A simple versatile non disruptive method for the isolation of morphologically and chemically pure basement membranes from several tissues. Life Sci 17: 1721-1732, 1975.

33. Burra P, Tomat S, Conconi MT, Macchi C, Russo FP, Parnigotto PP, Naccarato R and Nussdorfer GG: Acellular liver matrix improves the survival and functions of isolated rat hepatocytes cultured in vitro. Int J Mol Med 14: 511-515, 2004.

34. Katsura N, Ikai I, Mitaka T, Shiotani T, Yamanokuchi S, Sugimoto S, Kanazawa A, Tarajima H, Mochizuchi Y and Yamaoka Y: Long-term culture of primary human hepatocytes with preservation of proliferative capacity and differentiated functions. J Surg Res 106: 115-123, 2002.

35. Albertin G, Carraro G and Nussdorfer GG: Human adrenomedullin gene silencing by short interfering RNAs: A preliminary study. Int J Mol Med 15: 579-583, 2005.

36. Albertin G, Carraro G, Petrelli L, Guidolin D, Neri G and Nussdorfer GG: Endothelin-1 and adrenomedullin enhance the growth of human adrenocortical carcinoma-derived SW-13 cell line by stimulating proliferation and inhibiting apoptosis. Int $\mathbf{J}$ Mol Med 15: 469-474, 2005.

37. Rucinski M, Albertin G, Spinazzi R, Ziolkowska A, Nussdorfer GG and Malendowicz LK: Cerebellin in the rat adrenal gland: Gene expression and effects of CER and [des-Ser1]CER on the secretion and growth of cultured adrenocortical cells. Int J Mol Med 15: 411-415, 2005.

38. Andreis PG, Rucinski M, Neri G, Conconi MT, Petrelli L, Parnigotto PP, Malendowicz LK and Nussdorfer GG: Neuropeptides B and W enhance the growth of human adrenocortical carcinoma-derived NCI-H295 cells by exerting MAPK p42/p44-mediated proliferogenic and antiapoptotic effects. Int J Mol Med 16: 1021-1028, 2005.

39. Sargent TD, Yang M and Bonner J: Nucleotide sequence of cloned rat serum albumin messenger RNA. Proc Natl Acad Sci USA 78: 243-246, 1981.
40. Kaufmann PM, Sano K, Uyama S, Breuer CK, Organ GM, Schloo BL, Kluth D and Vacanti JP: Evaluation of methods of hepatotrophic stimulation in rat heterotopic hepatocyte transplantation using polymers. J Pediatr Surg 34: 1118-1123, 1999.

41. Kaufmann PM, Sano K, Uyama S, Takeda T and Vacanti JP: Heterotopic hepatocyte transplantation: assessing the impact of hepatotrophic stimulation. Transplant Proc 26: 2240-2241, 1994.

42. Mooney D, Hansen L, Vacanti JP, Langer R, Farmer S and Ingber D: Switching from differentiation to growth in hepatocytes: control by extracellular matrix. J Cell Physiol 151: 497-505, 1992

43. Block GD, Locker J, Bowen WC, Petersen BE, Katyal S, Strom SC, Riley T, Howard TA and Michalopoulos GK: Population expansion, clonal growth, and specific differentiation patterns in primary cultures of hepatocytes induced by $\mathrm{HGF} / \mathrm{SF}$, EGF, and TGF alfa in a chemically defined (HGM) medium. J Cell Biol 132: 1133-1149, 1996.

44. Kaufmann PM, Fiegel HC, Kneser U, Pollok JM, Kluth D and Rogiers X: Influence of pancreatic islets on growth and differentiation of hepatocytes in co-culture. Tissue Eng 5: 583-596, 1999.

45. Mizuguchi T, Hui T, Palm K, Sugiyama N, Mitaka T, Demetriou AA and Rotzga J: Enhanced proliferation and differentiation of rat hepatocytes cultured with bone marrow stromal cells. J Cell Physiol 189: 106-119, 2001.

46. Rickheim DG, Nelsen CJ, Fassett JT, Timchenko NA, Hansen LK and Albrecht JH: Differential regulation of cyclins D1 and D3 in hepatocyte proliferation. Hepatology 36: 30-38, 2002.

47. Walldorf J, Aurich H, Cai H, Runge D, Christ B, Strom SC and Fleig WE: Expanding hepatocytes in vitro before cell transplantation: donor age-dependent proliferative capacity of cultured human hepatocytes. Scand J Gastroenterol 39: 584-593, 2004.

48. Ouyang EC, Wu CH, Walton $\mathrm{C}$, Promrat $\mathrm{K}$ and Wu GY: Transplantation of human hepatocytes into tolerized genetically immunocompetent rats. World J Gastroenterol 7: 324-330, 2001.

49. Chen S, Wang HT, Yang B, Fu YR and Ou QJ: Protective effects of recombinant human growth hormone on cirrhotic rats. World J Gastroenterol 10: 2894-2897, 2004.

50. Gomez-Lechon MJ, Jover R, Donato T, Ponsoda X, Rodriguez C, Stenzel KG, Klocke R, Paul D, Guillen I, Bort R and Castell JV: Long-term expression of differentiated functions in hepatocytes cultured in three-dimensional collagen matrix. J Cell Physiol 177: 553-562, 1998

51. Dunn TB, Kumins NH, Raofi V, Holman DM, Mihalov M, Blanchard J, Law WR, Rastellini C and Benedetti E: Multiple intrasplenic hepatocyte transplantations in dalmatian dog. Surgery 127: 193-199, 2000.

52. Uyama S, Kaufmann PM, Takeda T and Vacanti JP: Delivery of whole liver-equivalent hepatocyte mass using polymer devices and hepatotrophic stimulation. Transplantation 55: 932-935, 1993.

53. Rozga J: Repeated intraportal hepatocyte transplantation in analbuminemic rats. Cell Transplant 4: 237-243, 1995.

54. Gomez N, Balladur P, Calmus Y, Baudrimont M, Honiger J, Delelo R, Myara A, Crema E, Trivin F, Capeau J and Nordlinger B: Evidence for survival and metabolic activity of encapsulated xenogeneic hepatocytes transplanted without immunosuppression in Gunn rats. Transplantation 63: 1718-1723, 1997.

55. Tilles AW, Berthiaume F, Yarmush ML, Tompkins RG and Toner M: Bioengineering of liver assist devices. J Hepatobiliary Pancreat Surg 9: 686-696, 2002.

56. Wesolowska A, Olszewski WL and Durlik M: Transplantation of hepatocytes: elimination of recipient natural killer cells with irradiation and bone marrow reconstitution prevent early graft dysfunction. Transplant Proc 35: 2358-2360, 2003. 